\title{
The Model of Productivity and Efficiency on Fish Catching Results in Coastal Fishermen City of Padang
}

\author{
Hasdi Aimon', Melti Roza Adri', Elida ${ }^{3}$ \\ ${ }^{1}$ Dept. of Economics, Faculty of Economics, Universitas Negeri Padang, Padang, Indonesia \\ $\square$ (e-mail) hasdiaimon1955@gmail.com \\ 2Dept. of Economics, Faculty of Economics, Universitas Negeri Padang, Padang, Indonesia \\ $\triangle$ (e-mail)meltirozaadry@gmail.com \\ ${ }^{3}$ Faculty of Tourism and Hotel, Universitas Negeri Padang, Padang, Indonesia \\ $\square$ (e-mail) elidmpd@gmail.com
}

\begin{abstract}
Fishing is the main activity of the coastal fishermen of Padang City. Fishermen capture fish using three types of fishing gear; in boats motor, out boats motor and non-powered boats. The data used by the National Economic Survey, BPS, with a deep understanding of the survey results. The findings indicate that all input factors of the three fishing gears have significant effect on fish catch. The catch as a representation of fixed cost and variable cost also significantly affects the total cost of catching. The boats motor is more productive than the out boat motor, but more efficient. In addition, the out boats motor is more productive and efficient than a non-powered boat. Accordingly, this study recommends that fishing communities make changes and develop fishing gear from nonpowered boats to out boats motor. Furthermore, the local government is expected to make a credit program of fishermen business in the form of out boat motor purchase credit or subsidized price of out Boat motor.
\end{abstract}

Keywords: fishing catch, productivity, efficiency, cost of catch and variable cost.

\section{Introduction}

Coastal communities are already a marine potential management system in the coastal area of Padang City. Marine fishery resources have economic potential that can improve the living standards and welfare of fishermen in particular and the people of Padang in general. However, in reality there are still many fishermen who is not yet able to optimize their catch, so the income level of fishermen does not increase and the expected level of welfare has not been achieved. There are many variations in many coastal areas of the world to increase fish catches such as lighting arrangements (Adams, 2016), (Torgeir et al., 2013), (Dell, Wilcox, Matear, Chamberlain, \& Hobday, 2014) and (Bradburn \& Keller, 2015).

Catching device can be used to improve the catch, so it can be an alternative to achieve the expected productivity. In addition, catching cost arrangements can be an efficient cost-benefit option with certain fishing gear (Herrmann, Sistiaga, Rindahl, \& Tatone, 2016) (Chavez \& Williard, 2017) and (Grimaldo, Sistiaga, \& Larsen, 2014). Then, the combination of fishing gear and fleet behavior in achieving the productivity and efficiency of the catch is important (Cosgrove, Sheridan, Minto, \& Officer, 2014), (Edyvane \& Penny, 2017).

Based on the fish catch in the coastal area of Padang City from year 2004 to 2013, there was an average trend of increase in fish catches per year of 5.02 percent and the development rate of fish price per year of 4.93 percent (BPS, 2013; processed). Nevertheless, the average productivity per fisherman for each fishing is IDR. 308.445,00. The productivity of fishermen without Boat fishing gear and boats without a motor for each fishing is still below the average of this productivity of IDR $285.326,00$ and IDR 130.111,00. Therefore, the income of fishermen has not increased enough to fulfill the basic needs in their lives. Human lives require a sense of security and happiness when basic needs (clothing, food and shelter) can be met as well as the protection of major risks that threaten the life. 
In addition to the problems above, the coastal fishermen of Padang City are still experiencing problems in input factors, working capital, fishing cost, distance to fishing, and duration of fishing. Consequently, the fishing period of fishermen becomes irregular so the catch is not as expected of the fishermen. Additionally, the fish catches have been able to fulfill the local demand and in certain periods exceed the local demand hence impacting the fish price. This condition is actually an opportunity to improve the income and welfare of fishermen (Macusi, Katikiro, \& Babaran, 2017) and (Korman \& Yard, 2017). The increased productivity of fishermen catch needs to be improved so that Padang City becomes an exporter area of marine fish (Hilborn \& Costello, 2017).

The development of economic activities in the field of marine fisheries is an effort to change the pattern of the fishing community. As stated by Satria and Matsuda, (2003), decentralization is highly regarded as an alternative to make a better fisheries management. This is because decentralization has emerged as a mean to increase the efficiency and equity of fish delivery activities and service, and the increase of regional participation in the marine fisheries economic activities (Macusi et al., 2017). The evolution of decentralization of fisheries management policy in Indonesia shows that decentralization has gradually developed from de-concentration and delegation to the form of devolution. With this devolution, community-based management system is recognized rooted from traditional fishing communities. The effectiveness of community-based management system based on marine resource sustainability is due to bottom-up planning and participatory approach that increases the meaning of local fishermen's management of resources. This article identifies several agendas currently faced at local and national levels; it is also related with the need to improve legal framework, the increase of regional government capacity and the revitalization of local fisheries institutions.

Then, according to DeMers and Kohui, (2011) that the development and social changes of fishing communities have changed the fishing nature of fishing communities in Fiji. This article tries to consolidate some aspects of decentralization of fisheries development of Fiji to encourage long-term sustainability and economic viability of fishermen from Fiji's marine resources. In addition, this article also provides an overview that connects the context of fisheries development with economic policies to address over fishing. This analysis also highlights a comprehensive management approach that includes the integration of offshore fisheries and coastal waters of Fiji to ensure the achievement of the economic benefits of fishing communities in the long term.

Furthermore, Sunoko and Huang, (2013) stated that tuna fish contributes significantly to the fishery economy of Indonesia and the world. Indonesian tuna fisheries were introduced to Japan, Taiwan and Korea. Indonesia's long coastline made foreign ships switch to Indonesian flag in tuna fishing in Indonesia. Through this effort, Indonesia has become one of the tuna-producing countries in 2014 and experienced increase of sea fisheries catch by 5 percent per year from 2010 to 2014 . Tuna fisheries regional management or organizations tried to manage tuna fisheries by the strength of stock conservation to enhance international cooperation. As a result, Indonesia adopted international regulations to comply with fisheries management measures. For sustainable development in the future, Indonesia needs to build capacity, increase regulations with tuna conservation and management, increase production to improve fish quality and diversification, and through international cooperation enhancement.

\section{Methods}

Production function has properties such as utility functions. If the input increases, output also increases. But, the addition of first input will give a greater additional output compared to the additional output caused by the subsequent additional input. This property is called law of diminishing return (Case \& Fair, 2007:144). Graphically, ceteris paribus, the production function of labor $(\mathrm{L})(\mathrm{K}$ is assumed to be fixed), then $\mathrm{Q}(\mathrm{L})$ is as follows: 


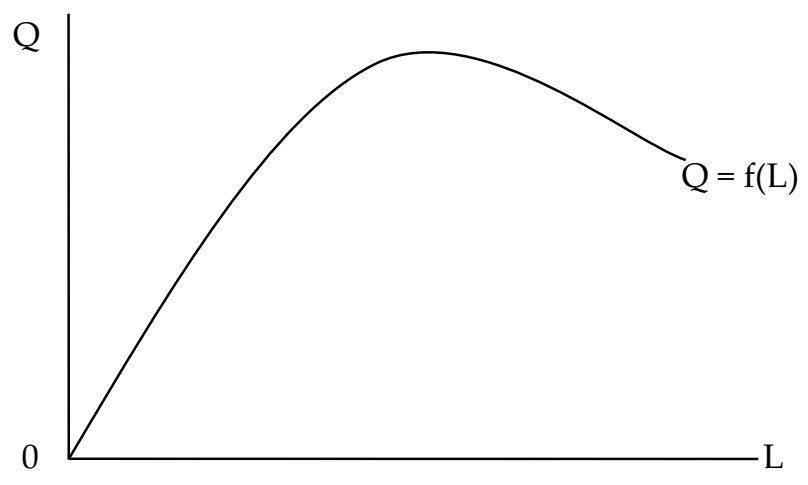

Source: Case \& Fair $(2007,144)$

Figure 1 The production function

Mathematically, the nature of the increased production function (if input increases then output increases) is indicated by the positive result of first derivative of $Q$ to $L$. Meanwhile, the decreasing nature of the increase (representing law of diminishing return) is indicated by a negative result of second derivative of $\mathrm{Q}$ to $\mathrm{L}$ (concave curve).

Mankiw (2006:336) said that every production process has a technical foundation, which in economic theory is called production function. Production function is a function or equation that shows the relationship between the level of output and the level combination of inputs usage. Every manufacturer in theory is considered to have a production function as follows (Mankiw, 2006, 336):

$Q=f\left(X_{1}, X_{2}, X_{3}\right.$ $\left.X_{n}\right)$

Explanation:

$\mathrm{Q}=$ production level

$\mathrm{X}_{1}, \mathrm{X}_{2}, \mathrm{X}_{3} \ldots . \mathrm{X}_{\mathrm{n}}=$ various inputs used

In regards to Law of Diminishing Returns, Mankiw also stated that in economic theory there is one basic assumption used regarding the property of production function. That is the production function from all production in which all the manufacturers are deemed subject to a law called The Law of Diminishing Return. Mankiw (2006:337) also said that this law explains if the use of one input is increased while the other inputs are fixed, then the additional output generated will initially rise, but then decreases as the inputs continue to be added.

Production function of Cobb-Douglas is a function or equation that involves two or more variables. The one variable is called dependent, which is described $(Y)$, and the other variable is called independent variable that explains $(X)$ (Bilas, 2008:154). The settlement of relationship between $X$ and $\mathrm{Y}$ is usually with regression, in which the variation of $\mathrm{Y}$ will be influenced by the variation of $\mathrm{X}$. Therefore, this study uses production model as follows:

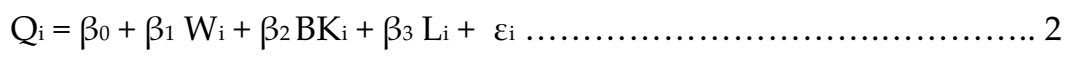

Where:

$\mathrm{Q}_{\mathrm{i}} \quad=$ fish catch in one time fishing with certain fishing gear

$\mathrm{W}_{\mathrm{i}} \quad$ = labor cost in one time fishing with certain fishing gear

$\mathrm{BK}_{\mathrm{i}} \quad=$ composite cost in one time fishing with certain fishing gear

$\mathrm{Li} \quad=$ labor involved in one time fishing with certain fishing gear

$\beta_{0} \quad=$ intercept

$\beta_{1} \ldots \beta_{3}=$ co-efficient variables

$\varepsilon_{\mathrm{i}} \quad=$ Error term.

Therefore, to see the productivity of the catch per labor then the model is modified by dividing the above model (equation 3 ) into the equation 4 below.

$\mathrm{Q}_{\mathrm{i}} / \mathrm{Li}_{\mathrm{i}}=\beta_{0}+\beta_{1} \mathrm{~W}_{\mathrm{i}} / \mathrm{Li}+\beta_{2} \mathrm{BKi} / \mathrm{Li}+\beta_{3} \mathrm{Li} / \mathrm{Li}+\varepsilon_{\mathrm{i}}$ 3 
Furthermore, the model in equation 4 will be estimated using the following equation.

$\log q_{i}=\beta_{0}+\beta_{1} \log w_{i}+\beta_{2} \log b k_{i}+\varepsilon_{i}$ 4

The results of this estimate will show the productivity of fishermen per fishing gear used for each time to go to sea. In addition, it will also explain the average productivity per fisherman per fishing gear.

The total cost per fisherman function for each fishing gear used is to show the functional relationship between the total cost per fisherman determined by the productivity of the catch per fisherman. Based on the structural model the total cost per fisherman is transformed directly in the following logarithm.

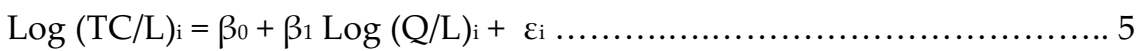

Where:

$(\mathrm{TC} / \mathrm{L})_{\mathrm{i}}=$ Total cost per fisherman based on fishing gear.

$(\mathrm{Q} / \mathrm{L})_{\mathrm{i}}=$ Productivity of catch per fisherman for each fishing gear.

$\beta_{0} \quad=$ Fixed cost coefficient per fisherman before antilog.

$\beta_{1} \quad=$ Variable cost coefficient per each catch per fisherman.

\section{Results and Discussion}

\section{Potential Fisheries of Padang City}

The potential of sea fisheries in the coastal area of Padang City is quite high seen from the long coastline and number of districts near the sea. Coastal area of Padang City has a beach area that consists of; (a) Koto Tangah District, (b) North Padang District, (c) West Padang District, (d) South Padang District, (e) Bungus Teluk Kabung District. Geographically, in these five districts there are still fishermen who catch fish by using certain fishing gears. There are 3 (three) fishing gears observed in this study, namely; (a) In Boat Motor, (b) Out Boat Motor, and (c) Non-powered Boat.

Table 1 Percentage of household marine fishing by type of ship/boat, marine management area (WPP) and how to catch fish

\begin{tabular}{|c|c|c|c|c|c|c|}
\hline \multirow[b]{3}{*}{ Type of Ship/Boat } & \multicolumn{6}{|c|}{ Marine Management Area (WPP) } \\
\hline & \multicolumn{2}{|c|}{ WPP - RI 571} & \multicolumn{2}{|c|}{ WPP - RI 572} & \multicolumn{2}{|c|}{ WPP - RI 573} \\
\hline & $\begin{array}{c}\text { Individ } \\
\text { ual } \\
\end{array}$ & $\begin{array}{l}\text { Joint/ } \\
\text { Group }\end{array}$ & $\begin{array}{c}\text { Individ } \\
\text { ual }\end{array}$ & $\begin{array}{l}\text { Joint/ } \\
\text { Group }\end{array}$ & Individual & $\begin{array}{l}\text { Joint/ } \\
\text { Group }\end{array}$ \\
\hline 1. Motor Boat & 1.18 & - & 24.71 & 74.11 & - & 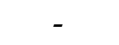 \\
\hline 2. Out Boat Motor Boats & 0.19 & - & 71.22 & 28.46 & 0.13 & - \\
\hline 3. Non-powered Boats & 7.27 & - & 86.73 & 2.64 & 3.17 & 0.19 \\
\hline Rata-rata & 3.64 & - & 61.89 & 35.13 & 1.65 & 0.19 \\
\hline
\end{tabular}

Source: BPS, Census of Agriculture, 2013.

\section{Results and Costs of Fishing}

The average of catch and fishing cost per day per fisherman will vary depending on the fishing gear used. In one trip In Boat Motor takes three days with an average catch of $301.91 \mathrm{~kg}$. Thus, in one day the average catch of In Boat Motor is $100.64 \mathrm{~kg}$. The average crew of ship is 4.69 people rounded to 5 people, then the average catch per person is $20.13 \mathrm{~kg}$. Meanwhile, in one trip Out Boat Motor takes 1 day in average and catch of $27.40 \mathrm{~kg}$. The average crew of the ship is 2.26 people rounded to 2 people, then the average catch per person in one day is $13.70 \mathrm{~kg}$. Meanwhile, if using Non-powered Boat with an average passengers of 1.11 people rounded to 1 people, the catch amounts to $10.17 \mathrm{~kg}$. Thus, the more modern fishing gear is used, the higher the average catch per person per day will be. 
The comparison between catch, cost of catch and income based on fishing gear used can be seen in Table 2, Table 3 and Table 4 below.

Table 2 Results and costs structure of marine fishing per trip using in boat motor

\begin{tabular}{|c|c|c|c|}
\hline \multirow{2}{*}{ Cost Type } & \multicolumn{3}{|c|}{ In Boat Motor } \\
\hline & Volume (Kg) & Value (IDR 000) & $\%$ \\
\hline Average Number of Days per Trip & \multicolumn{3}{|c|}{3 days } \\
\hline 1. Production & 301.91 & 4,073 & 100.00 \\
\hline 2. Cost & - & 2,700 & 66.29 \\
\hline 3. Incomes & - & 1,373 & 33.71 \\
\hline
\end{tabular}

Source: BPS, Census of Agriculture, 2013.

Table 2 above shows that for fishermen using In Boat Motor fishing gear, the ratio of catch cost to the catch is 66.29 percent and the ratio of fishermen income to the catch is 33.71 percent. This means that the average income of fishermen in one day is IDR91,533.33. Meanwhile, Out Boat Motor fishing gear shows that the ratio of catch cost to the catch is 73.76 percent and the ratio of fishermen income to the catch is 26.24 percent. This means that the average income of fishermen in one day is IDR 60,500.00 (see Table 3), indicating that In Boat Motor fishing gear is more productive and efficient when compared to Out Boat Motor fishing gear.

Table 3 Results and costs structure of marine fishing per trip using out boat motor

\begin{tabular}{|l|r|r|r|}
\hline \multirow{2}{*}{ Cost Types } & \multicolumn{3}{|c|}{ Out Boat Motor } \\
\cline { 2 - 4 } & Volume (Kg) & Value (IDR 000) & \multicolumn{2}{c|}{$\%$} \\
\hline Average Number of Days per Trip & 27.40 & 460 & 100.00 \\
\hline 1. Production & - & 339 & 73.76 \\
2. Cost & - & 121 & 26.24 \\
3. Incomes & \multicolumn{3}{|c|}{ 1 day } \\
\hline
\end{tabular}

Source: BPS, Census of Agriculture, 2013.

In addition, when comparing Out Boat Motor with non-powered Boat fishing gear as seen in Table 3 , it shows that the ratio of catch cost to the catch is 73.76 percent and the ratio of fishermen income to the catch is 26.24 percent. This means that the average income of fishermen in one day is IDR $30.000,00$, indicating that Out Boat Motor fishing gear is more productive and efficient when compared to non-powered Boat fishing gear.

If fishermen replace their fishing gears from non-powered Boat to Out Boat Motor then their income will increase by 101.67 percent. And if fishermen change fishing gears from Out Boat Motor to In Boat Motor then their income will increase by 51.29 percent.

Table 4 Results and costs structure of marine fishing per trip using non-powered boat

\begin{tabular}{|l|r|r|r|}
\hline \multirow{2}{*}{ Cost Types } & \multicolumn{3}{|c|}{ Non-powered Boat } \\
\cline { 2 - 4 } & Volume (Kg) & Value (IDR 000) & \multicolumn{2}{c|}{$\%$} \\
\hline Average Number of Days per Trip & \multicolumn{3}{|c|}{1} \\
\hline 1. Production & 10.17 & 154 & 100.00 \\
2. Cost & - & 124 & 80.58 \\
3. Incomes & - & 30 & 19.42 \\
\hline
\end{tabular}

Source: BPS, Census of Agriculture, 2013.

\section{Determinant of Fish Catch}

The estimated catch per fisherman, $(\mathrm{Q} / \mathrm{L})$ based on fishing gear is determined by two main factors in fishing i.e. (1) wage per fisherman, (W/L), and (2) composite cost per fisherman (BK/L). Composite cost consists of; Gasoline, Diesel Fuel, Kerosene, Lubricants, Salt, Ice and Bait. Both of these factors become the determinants of fish catch per fishing gear during fishing.

Table 4 above shows that the three fishing gears show the condition of increasing return to scale. This shows us that Out Boat Motor fishing gear is more elastic (1.2900) compared to other fishing 
gears (1.2621 and 1.2389). Likewise, the wage coefficient per fisherman (W/L) of Out Boat Motor fishing gear also shows a bigger coefficient $(0.8082)$ when compared to other fishing gears $(0.4796$ and 0.7967). This means that the role of fishermen is very significant in obtaining the catch. Thus, Out Boat Motor fishing gear has a strategic role in improving the welfare of fishermen in the future. Estimated result of fish catch per fisherman can be seen in Table 5 below.

Table 5 Estimated fish catch

\begin{tabular}{|l|r|r|r|r|}
\hline \multirow{2}{*}{ Descriptions } & \multicolumn{5}{|c|}{ Fishing Gear } \\
\cline { 2 - 5 } & In Boat Motor & $\begin{array}{c}\text { Out Boat } \\
\text { Motor }\end{array}$ & $\begin{array}{c}\text { Non-powered } \\
\text { Boat }\end{array}$ & \multicolumn{1}{c|}{ All } \\
\hline Log (W/L) & 0.4796 & 0.8082 & 0.7967 & 0.7630 \\
\hline t-statistic & 7.0753 & 33.2024 & 20.2930 & 38.0193 \\
\hline Log (BK/L) & 0.7825 & 0.4818 & 0.4422 & 0.5158 \\
\hline t-statistic & 12.4854 & 19.6845 & 10.8318 & 25.6423 \\
\hline Increasing Return to Scale & 1.2621 & 1.2900 & 1.2389 & 1.2788 \\
\hline Average Productivity $(\mathrm{Kg})$ & 271.533 & 230.000 & 154.00 & 167.162 \\
\hline
\end{tabular}

Source: Census of Agriculture, 2013 (processing).

\section{Determinant of Catch Fish Cost}

The fish catch in one fishing trip using In Boat Motor fishing gear is in average IDR 4,073,000 in 3 days with 5 fishermen. Therefore, the catch that can be obtained in one day per fisherman is IDR 271,533.33. Meanwhile, the cost used to obtain this catch by using In Boat Motor fishing gear is IDR 2,700,000.00. Thus, it can be obtained that the cost of catch in one day per fisherman is IDR 180,000.00.

If fishermen use Out Boat Motor during fishing then the catch is IDR 230,000.00 per day per fisherman. Meanwhile, the cost of catch is IDR 169,500.00 per day per fisherman. Thus, when comparing the catch cost between these two fishing gears per day per fisherman, it shows that In Boat Motor fishing gear is more expensive (IDR180,000 : IDR169,500). This means that the working capital needed in the operational of In Boat Motor is higher compared to Out Boat Motor. However, larger catch was also obtained using In Boat Motor fishing gear (IDR271,533: IDR 230,000).

Furthermore, if fishermen use Non-powered Boat fishing gear during fishing then the catch per one day per fisherman is IDR $154,000.00$ with a catch cost of IDR 124,000.00 per day per fisherman. The result of estimated catch to the catch cost can be seen in Table 6 below.

Table 6 Estimated of catch fish cost

Dependence Variable $\log (\mathrm{TC} / \mathrm{L})$

\begin{tabular}{lrrrr}
\hline \multirow{2}{*}{ Items } & \multicolumn{4}{c}{$\log (\mathrm{TC} / \mathrm{L})=(\mathrm{FC})+\mathrm{VC} \log (\mathrm{Q} / \mathrm{L})$} \\
\cline { 2 - 5 } & In Boats Motor & $\begin{array}{c}\text { Out Boats } \\
\text { Motor }\end{array}$ & $\begin{array}{c}\text { Non-powered } \\
\text { Boats }\end{array}$ & \multicolumn{1}{c}{ All } \\
\hline $\mathrm{C}($ Constant) & 0.1633 & 2.3137 & 2.0758 & 1.8435 \\
\hline $\mathrm{t}-$-Statistic & 0.5238 & 21.7199 & 15.4210 & 232617 \\
\hline $\mathrm{Log}(\mathrm{Q} / \mathrm{L})$ & 0.8857 & 0.4814 & 0.5143 & 0.5756 \\
\hline $\mathrm{t}$-Statistic & 9.4947 & 23.4922 & 17.6095 & 37.4268 \\
\hline Average Cost per Labor (IDR) & 180,000 & 169,500 & 124,000 & 157,667 \\
\hline Source: Census of Agriculture, 2013 (processing). & & & &
\end{tabular}

Table 6 above shows that the comparison of cost coefficients of catch variables is $0.8857,0.4814$, and 0.5143 , respectively. This means that the most efficient variable cost is if fishermen use Out Boat Motor fishing gear instead of using In Boat Motor and Non-powered Boat. By using Out Boat Motor fishing gear there is 100 percent increase of catch, while the catch cost only increased by 48,14 percent. However, using In Boat Motor and Non Powered Boat fishing gears will increase cost by 88,57 percent and 51,43 percent. 


\section{Conclusions}

The conclusion of this paper shows that the more productive fish catch per-fishermen is using In Boat Motor compared to other fishing gears. Likewise, the efficiency of catch cost per-fishermen shows that In Boat Motor fishing gear is more efficient compared to other fishing gears. Accordingly, it is recommended to the fishermen of coastal area Padang City in improving the welfare there needs to be an effort to shift fishing gears from Non-powered Motor to Out Boat Motor. Similarly, the local government of Padang City through the Office of Fisheries and Marine needs to create a policy that encourages the development of use of Out Boat Motor fishing gear.

\section{Acknowledgments}

This paper comes from a study that supported by research team Mrs. Melti Roza Adry, and Mrs. Elida. The main data of the study is sourced from Census of Agriculture, BPS. Then assisted by students involved in in-depth survey. This research is funded by DRPM Kemenristek Dikti, Republik Indonesia. Therefore, we would like to thank all those who have contributed to this research and paper.

\section{References}

Adams, A. J. (2016). Guidelines for evaluating the suitability of catch and release fisheries: Lessons learned from Caribbean flats fisheries. Fisheries Research. http://doi.org/10.1016/j.fishres.2016. 09.027

Badan Pusat Statistik. (2013). Padang dalam Angka. Padang: Badan Pusat Statistik.

Bilas, Richard A. (2008). Teori Mikroekonomi. Jakarta: Erlangga.

Bradburn, M. J., \& Keller, A. A. (2015). Impact of light on catch rate of four demersal fish species during the 2009 - 2010 U . S . west coast groundfish bottom trawl survey. Fisheries Research, 164, 193-200. http://doi.org/10.1016/j.fishres.2014.11.010

Case \& Fair. (2007). Prinsip-Prinsip Ekonomi Mikro. Zaimur, Y. Andri (Translator). Jakarta: Erlangga.

Chavez, S., \& Williard, A. S. (2017). The effects of bycatch reduction devices on diamondback terrapin and blue crab catch in the North Carolina commercial crab fishery. Fisheries Research, 186, 94101. http://doi.org/10.1016/j.fishres.2016.08.010

Cosgrove, R., Sheridan, M., Minto, C., \& Officer, R. (2014). Application of finite mixture models to catch rate standardization better represents data distribution and fleet behavior. Fisheries Research, 153, 83-88. http://doi.org/10.1016/j.fishres.2014.01.005

Dikrurahman \& Tubagus Furqon Sofhani. (2012). Faktor-Faktor yang mempengaruhi pengembangan kelompok nelayan dalam upaya pemberdayaan masyarakat nelayan (Studi kasus: Kelompok nelayan di Pulau Temoyong, Kecamatan Bulang, Kota Batam). Jurnal Perencanaan Wilayah dan Kota B SAPPK, 2(1), 35 - 44.

Dell, J. T., Wilcox, C., Matear, R. J., Chamberlain, M. A., \& Hobday, A. J. (2014). Deep-sea research II potential impacts of climate change on the distribution of longline catches of yellow fin tuna (Thunnus albacares) in the Tasman sea. Deep-Sea Research Part II, 1-11. http://doi.org/10.1016/j. dsr2.2014.07.002

Edyvane, K. S., \& Penny, S. S. (2017). Trends in derelict fishing nets and fishing activity in northern Australia: Implications for trans-boundary fisheries management in the shared Arafura and Timor Seas. Fisheries Research, 188, 23-37. http://doi.org/10.1016/j.fishres.2016.11.021

Eko, Salmani \& Bambang Indratno Gunawan. (2013). Studi tingkat kesejahteraan masyarakat nelayan di Kampung Gurimbang Kecamatan Sambaliung Kabupaten Berau. Jurnal Ilmu Perikanan Tropis, $18(2)$.

Gasperz, Vincent. (2005). Ekonomi Manajerial Pembuatan Keputusan Bisnis. Jakarta: PT Gramedia Pustaka Utama.

Grimaldo, E., Sistiaga, M., \& Larsen, R. B. (2014). Development of catch control devices in the Barents Sea cod fishery. Fisheries Research, 155, 122-126. http://doi.org/10.1016/j.fishres.2014.02.035 
Herrmann, B., Sistiaga, M., Rindahl, L., \& Tatone, I. (2016). Estimation of the effect of gear design changes on catch efficiency: Methodology and a case study for a Spanish longline fishery targeting hake (Merluccius merluccius). Fisheries Research. http://doi.org/10.1016/j.fishres.2016. 09.013 .

Hilborn, R., \& Costello, C. (2017). The potential for blue growth in marine fish yield, profit and abundance of fish in the ocean. Marine Policy, (February), 1-6. http://doi.org/10.1016/j.marpol. 2017.02.003

Indriantoro, Nur \& Bambang Supomo. (1999). Metodologi Penelitian Bisnis: Untuk Akuntansi \& Manajemen. Yogyakarta: BPFE.

Joesron, Tati Suhartati \& Fathorozi, M. (2003). Teori Ekonomi Mikro. 1 ${ }^{\text {st }}$ ed. Jakarta: Salemba Empat.

Korman, J., \& Yard, M. D. (2017). Effects of environmental covariates and density on the catchability of fish populations and interpretation of catch per unit effort trends. Fisheries Research, 189, 1834. http://doi.org/10.1016/j.fishres.2017.01.005

Mankiw, N. Gregory. (2006). Pengantar Ekonomi Mikro. (Chriswan Sungkono. Terjemahan). Jakarta : Salemba Empat. Buku asli diterbitkan tahun 2004.

Macusi, E. D., Katikiro, R. E., \& Babaran, R. P. (2017). The influence of economic factors in the change of fi shing strategies of anchored FAD fi shers in the face of declining catch, General Santos City, Philippines. Marine Policy, 78(October 2016), 98-106. http://doi.org/10.1016/j.marpol.2017.01.016

Pindyck, Robert S. dan Daniel L. Rubinfeld. (2003). Mikroekonomi. (Aldi Jenie. Terjemahan). Jakarta : PT.Indeks. Buku asli diterbitkan tahun 2001.

Retnowati, Herlina, et al. (2014). Strategi peningkatan kinerja nelayan dalam rantai pasok ikan layur melalui pengembangan modal insani di pelabuhan ratu. Jurnal Manajemen IKM, 9(2), 140 - 149.

Salvatore, Dominick. (2007). Mikroekonomi. (Rudy Sitompul. Terjemahan). Jakarta : Erlangga. Buku asli diterbitkan tahun 2006.

Sugiharto, Eko. (2007). Tingkat kesejahteraan nelayan desa benua baru ilir berdasarkan indikator badan pusat statistik. Jurnal EPP, 4(2), 32-36.

Todaro, Michael P \& Stephen C. Smith. (2011). Economic Development. United States: Addison Wiley.

Torgeir, B., Gabrielsen, S., Løyland, J., Schläppy, M., Wiers, T., Wiik, K., \& Pulg, U. (2013). Trap design for catching fish unharmed and the implications for estimates of sea lice (Lepeophtheirus salmonis ) on anadromous brown trout (Salmo trutta). Fisheries Research, 139, 43-46. http://doi.org/10.1016/j.fishres.2012.01.024 